Alina Jurcewicz ${ }^{1}$

\title{
Wpływ ustawy z dnia 14 kwietnia 2016 r. o wstrzymaniu sprzedaży nieruchomości Zasobu Własności Rolnej Skarbu Państwa na kształtowanie ustroju rolnego - zagadnienia wybrane
}

1.

Problematyka kształtowania struktur agrarnych zazwyczaj zajmuje centralne miejsce w unormowaniach prawnych dotyczących rolnictwa. Aktywność legislacyjna państwa skupia się zatem na określeniu modelu relacji własnościowych w rolnictwie i preferencji w zakresie normatywnych podstaw obrotu nieruchomościami rolnymi, a więc zagadnień fundamentalnych w kontekście produkcyjności sektora rolnego i funkcjonowania społeczności wiejskiej². Kontekst ten sprawia, że problematyka „własnościowa” ma szczególną rangę w sferze regulacji normatywnej rolnictwa. W niej bowiem następuje odzwierciedlenie przyjmowanych przez ustrojodawcę założeń ideowych dotyczących ustroju rolnego państwaª

Nie ulega wątpliwości, że regulacje prawne z zakresu kształtowania ustroju rolnego odgrywają też istotną rolę w sferze gospodarczej i politycznej. Określone przez prawodawcę ramy normatywne dla kształtowania się stosunków własnościowych

$1 \quad$ Instytut Nauk Prawnych PAN.

2 Por. A. Stelmachowski, (w:) T. Dybowski, System prawa prywatnego. Prawo rzeczowe. Tom 3, Warszawa 2007, s. 187-193; S. Prutis, Własność rolnicza według Profesora Andrzeja Stelmachowskiego, (w:) P. Czechowski (red.), Prawo rolne, Warszawa 2013, s. 44-45; T. Kurowska, Renesans własności rolniczej, „Przegląd Prawa Rolnego” 2014, nr 2, s. 28; A. Jurcewicz, P. Popardowski, Własność w ujęciu prawa polskiego i prawa UE, „Studia luridica Agraria” 2011, T. IX, s. 139; M. Korzycka-Iwanow, Ochrona własności rolniczej w nawiązaniu do koncepcji własności rolniczej Profesora Andrzeja Stelmachowskiego, „Studia luridica Agraria” 2011, T. IX, s. 119-121.

3 Por. np. K. Stefańska, Gospodarstwo rodzinne jako element ustroju rolnego, „Studia luridica Agraria” 2004, T. III, s. 171 i nast.; T. Kurowska, Gospodarstwo rodzinne w świetle art. 23 Konstytucji RP, (w:) K. Skotnicki, K. Winiarski (red.), Własność i jej ograniczenia w prawie polskim. Materiały konferencyjne, Częstochowa 2004, s. 45-59; P. Czechowski, Opinia indywidualna członka Rady Legislacyjnej do projektu ustawy o kształtowaniu ustroju rolnego państwa oraz zmianie niektórych innych ustaw, „Przegląd Legislacyjny” 2003, nr 2, s. 142-144; S. Prutis, Zróżnicowanie własnościowe gospodarstw rolnych - synchronizacja pojęć, „Studia luridica Agraria” 2014, T. XII, s. 7 i nast. Zob. również w kwestii oddziaływania własności na kształtowanie stosunków społecznych i gospodarczych w ujęciu ogólnym: W. Bienkowski, Problemy teorii rozwoju społecznego, Warszawa 1966, s. 151; M. Bednarek, Przemiany własności w Polsce. Podstawowe koncepcje i konstrukcje normatywne, Warszawa 1994, s. 7; J. Jabłońska-Bonca, Własność - w labiryncie interdyscyplinarnych problemów. Kilka uwag wstępnych, (w:) J. Jabłońska-Bonca (red.), Krytyka prawa. Niezależne studium nad prawem. Tom I. Własność, Warszawa 2009, s. 12. 
w rolnictwie przekładają się w sposób bezpośredni na rzeczywisty potencjał produkcyjny tego sektora ${ }^{4}$, a w szerszym ujęciu wpływają na poziom życia społeczności wiejskiej ${ }^{5}$. Odniesienia te mają także istotne znaczenie polityczne. Kształtowane w ten sposób zdolności produkcyjne rodzimego sektora rolnego służą zapewnieniu przez państwo bezpieczeństwa żywnościowego swoich obywateli ${ }^{6}$, a w relacjach zewnętrznych determinują jego niezależność żywnościową (ang. food sovereignty) ${ }^{7}$.

\section{2.}

W Polsce postulat poprawy struktury agrarnej od lat przywoływany jest jako zasadniczy motyw podejmowanych przez państwo różnorodnych inicjatyw legislacyjnych skierowanych do sektora rolnego. Znaczącym jest jednak, że pomimo wielokrotnie wyrażanych dążeń do wzmocnienia potencjału produkcyjnego rodzimego sektora rolnego poprzez oddziaływanie strukturalne (ochrona przed rozdrobnieniem gospodarstw rolnych, zapobieganie nadmiernej koncentracji produkcji rolnej oraz zapewnienie prowadzenia działalności rolniczej przez osoby posiadające odpowiednie kwalifikacje) podejmowane działania legislacyjne rzadko prowadziły do skutecznej eliminacji negatywnych zjawisk ujawniających się w tym obszarze gospodarki. Co więcej, mając na uwadze perspektywę historyczną można stwierdzić, że podnoszony argument poprawy struktury agrarnej niejednokrotnie stanowił jedynie werbalne uzasadnienie dla działań regulacyjnych dotyczących rolnictwa, służących w zasadzie realizacji doraźnych celów politycznych i w istocie rzeczy abstrahujących od rozwiązywania rzeczywistych problemów polskiej wsi i rolnictwa. Działania takie często wywoływały skutek odwrotny, potęgując niekorzystne tendencje i zjawiska strukturalne na polskiej wsi.

Zob. szerzej w tej kwestii: Z. Kołoszko-Chomentowska, L. Sieczko, Gospodarstwo rodzinne jako podmiot w gospodarce narodowej, „Economics and Management” 2014, nr 1, s. 97-107; W. Poczta, E. Szuba-Barańska, P. Beba, W. Czubak, Strukturalna i ekonomiczna różnorodność a możliwości rozwoju gospodarstw rodzinnych w UE, „Wieś i Rolnictwo” 2015, nr 1, s. 57-76; W. Michna, Ewolucja rodzinnych gospodarstw rolnych na rzecz uzyskania odpowiedniej zdolności konkurencyjnej i samowystarczalności żywnościowej kraju, (w:) Gospodarstwa rodzinne podstawą europejskiego rolnictwa, Warszawa 2011, s. 59-62.

5 Por. P. Prus, Współczesne problemy rolnictwa i obszarów wiejskich w Polsce, „Zeszyty Naukowe SGGW w Warszawie - Problemy Rolnictwa Światowego” 2008, t. 5, s. 134-136. Kontekst związany z oddziaływaniem koncepcji własności i kształtowanych na jej podstawie relacji własnościowych na rzeczywistość społeczną i gospodarczą analizowany jest w literaturze również w ujęciu ogólnym: por. J. Wawrzyniak, Władza a własność, czyli o wybranych problemach ewolucji stosunków między władzą polityczną a władzą ekonomiczną, (w:) J. Jabłońska -Bonca (red.), Krytyka prawa..., op. cit., s. 140-145; D. Mitręga, I. Ostrój, Wpływ państwa na zmiany struktury własnościowej w warunkach gospodarki rynkowej, (w:) J. Żabińska (red.), Państwo w gospodarce rynkowej, Katowice 1992, s. 41 i nast.

6 Por. R.F. Hopkins, Food security, policy options and the evolution of state responsibility, (w:) F. La Monde Tullis, W.L. Hollis (red.), Food, the state and international policy economy. Dilemmas of developing countries, Lincoln London 1986, s. 4-5; K. Mechlem, Food Security and the Right to Food in the Discourse of the United Nations, European Law Journal 2004, v. 10, nr 2, s. 637; D. Gualtieri, Right to Food, Food Security, and Food Aid Under International Law, or the Limits of a right-based approach, Future of Food: Journal on Food, Agriculture and Society 2013, v. 1, nr 2, s. 19-21.

7 Por. H.M. Haugen, Food Sovereignty - An Appropriate Approach to Ensure the Right to Food?, Nordic Journal of International Law 2009, v. 78, s. 264 i s. 273. 
Wspomniane skutki wynikały częstokroć z regulacji dotyczących obrotu nieruchomościami rolnymi, stanowionych w okresie PRL, które opierały się m.in. na wyróżnieniu obrotu takimi nieruchomościami w obszarze regulacji cywilnoprawnej. I chociaż w odniesieniu do środków produkcji rolnej - odmiennie niż w większości państw tzw. bloku wschodniego - nie zdecydowano się na ich jednorazowe i całościowe upaństwowienie ${ }^{9}$, to jednak mając na uwadze postanowienia wielu regulacji prawnorolnych, bardzo wyraźnie zarysowana była tendencja do stopniowego „uspołeczniania” nieruchomości rolnych stanowiących własność prywatną. Realizacja tego celu następowała głównie poprzez wprowadzenie rozbudowanego systemu ograniczeń w obrocie nieruchomościami rolnymi inter vivos i mortis causa ${ }^{10}$. Wymogi normatywne dotyczące przeniesienia własności nieruchomości rolnych inter vivos, a przede wszystkim praktyka ich stosowania przez organy państwowe, $\mathrm{W}$ swej istocie skutkowały wyłączeniem obrotu prywatnego ${ }^{11}$. W ujęciu merytorycznym rozwiązania te skorelowane były z przepisami dotyczącymi dziedziczenia gospodarstw rolnych. W oparciu o nie wprowadzono rozbudowane ograniczenia podmiotowe przy dziedziczeniu gospodarstw rolnych, co prowadziło do preferowania państwa w kręgu spadkobierców. Znaczącym jest przy tym, że przy powoływaniu się przez ustawodawcę na konieczność podejmowania działań legislacyjnych nastawionych na ograniczenie zjawiska rozdrobnienia gospodarstw rolnych oraz zapewnienie ich prowadzenia przez osoby posiadające odpowiednie kwalifikacje, mieliśmy raczej do czynienia z dążeniem do (przynajmniej częściowego) wkomponowania rolnictwa w założenia ideowe właściwe dla gospodarki opartej na systemie nakazowo-rozdzielczym niż, rzeczywistym dążeniem do poprawy struktury agrarnej polskiego rolnictwa. Podporządkowanie legislacji rolnej temu właśnie celowi, wbrew formalnie wyrażanym dążeniom do poprawy struktury agrarnej, w praktyce dysfunkcjonalnie oddziaływało na model stosunków własnościowych na polskiej wsi. Sprowadzało się ono do preferowania uspołecznionych form działalności rolniczej $^{12}$, w których produkcja prowadzona była w ramach wielkoobszarowych, ale często nieefektywnych gospodarczo, państwowych gospodarstwach rolnych (PGR). Sprzyjało to także nieformalnemu obrotowi nieruchomościami rolnymi oraz pogłę-

Por. A. Jurcewicz, Problematyka prawna ustawy o kształtowaniu ustroju rolnego (na tle zarysu historycznego w sferze obrotu nieruchomościami rolnymi), „Wieś i Rolnictwo” 2006, nr 1, s. 71-72 oraz W. Jurcewicz, Ewolucja regulacji prawnej dotyczącej gospodarowania gruntami rolnymi w latach 1944-1984, „Wieś i Rolnictwo” 1985, nr 1, s. 39.

9 Por. szerzej w tej kwestii P. Popardowski, (w:) K. Osajda (red.), Kodeks cywilny. Komentarz. Przepisy wprowadzające. Część ogólna. Własność i inne prawa rzeczowe. Tom I, Warszawa 2013, s. 258-260.

10 A. Jurcewicz, Problematyka prawna..., op. cit., s. 73.

11 A. Jurcewicz, P. Popardowski, Własność w rolnictwie - ujęcie systemowe z perspektywy prawa krajowego i unijnego, „Studia Prawnicze” 2014, nr 1, s. 36-37.

12 Taki model pozwalał na uspołecznienie pozostających dotychczas w rękach prywatnych pewnej liczby prywatnych gospodarstw rolnych, a tym samym możliwość - również na płaszczyźnie produkcji rolnej - realizacji podstawowego założenia ideologicznego państwa socjalistycznego, jakim był monopol państwa w odniesieniu do środków produkcji. Por. A. Jurcewicz, Problematyka..., op. cit., s. 75; A. Lichorowicz, Szczególny porządek dziedziczenia gospodarstw rolnych w Polsce po orzeczeniu Trybunału Konstytucyjnego z 31.01.2001 r., „Rejent” 2001, nr 9, s. 88-89; P. Popardowski, (w:) K. Osajda (red.), Kodeks..., op. cit., t. I, s. 256. 
bianiu się rozdrobnienia powierzchniowego gospodarstw rolnych pozostających poza sferą upaństwowienia ${ }^{13}$.

\section{3.}

Przemiany ustrojowe w Polsce po 1989 r. zaowocowały nowymi regulacjami prawnymi w przedmiocie obrotu nieruchomościami rolnymi. Zmiany koncentrowały się przede wszystkim na zniesieniu uprzywilejowania upaństwowionych form własności (w tym również własności rolnej) oraz zniesieniu odrębności obrotu nieruchomościami rolnymi na płaszczyźnie regulacji cywilnoprawnej ${ }^{14}$. Dla niektórych wynikająca $\mathrm{z}$ tego liberalizacja obrotu nieruchomościami rolnymi stanowiła stan właściwy, odzwierciedlający zasadnicze założenia ideowo-ustrojowe dotyczące gospodarki wolnorynkowej ${ }^{15}$. W przeważającej części wypowiedzi zasadnie jednak akcentowano konieczność wprowadzenia różnorodnych rozwiązań, które - uwzględniając uwarunkowania właściwe dla obrotu wolnorynkowego - będą jednocześnie oddziaływać stymulująco na funkcjonowanie sektora rolnego, w tym przede wszystkim poprzez kształtowanie efektywnej struktury agrarnej ${ }^{16}$. Podej-

13 Regulacja prawnorolna w okresie PRL w praktyce prowadziła do niemal całkowitego zahamowania obrotu nieruchomościami rolnymi. W literaturze zwraca się uwagę, że efekty takich rozwiązań normatywnych były negatywne. Podkreśla się, że niezwykle rygorystyczne ujęcie mechanizmu obrotu nieruchomościami rolnymi, a przede wszystkim praktyka stosowania właściwych rozwiązań normatywnych, prowadziło do osłabienia poczucia własności wśród chłopów, przyczyniając się tym samym do upadku szeregu gospodarstw rolnych. Praktyczne wykluczenie w pewnym czasie możliwości przeniesienia własności nieruchomości rolnych sprzyjało rozwojowi zjawiska nieformalnego obrotu nieruchomościami rolnymi. Znaczące jest to, że skutki owego nieformalnego obrotu były bardziej trwałe i dalekosiężne niż same, dość przecież radykalne, ograniczenia obrotu. Po pierwsze, w wyniku dokonywania wielkiej liczby nieformalnych transakcji obrotu ziemią, wystąpiło ogromne zamieszanie w stosunkach własnościowych na wsi. Z jednej strony nawarstwiały się niezgodności między stanem prawnym a stanem faktycznym, powodujące w dużej mierze dezaktualizację (tam gdzie w ogóle istniały) ksiąg wieczystych lub ewidencji gruntów. Po drugie, przeprowadzanie transakcji nieformalnych (w pewnych przypadkach akceptowanych nawet przez urzędników) wywoływało niekorzystne zmiany w świadomości prawnej rolników, w ich podejściu do prawa. W sytuacji „erozji” legalistycznych postaw, stanowiących skutek formalnego zahamowania obrotu gruntami rolnymi, utwierdziło się w chłopach przeświadczenie, że prawo można skutecznie omijać. Nastąpiło więc ogólne osłabienie poczucia praworządności wśród chłopów i aparatu urzędniczego. Zjawiska te w żaden sposób nie przyczyniały się do wzmacniania strukturalnego polskiego rolnictwa. Wręcz przeciwnie, potęgowały one chaos przy określaniu struktury własnościowej na wsi i w istocie wykluczały możliwość realnego oddziaływania państwa na wielkość gospodarstw rolnych, a tym samym ich potencjał produkcyjny.

14 Jednym z podstawowych założeń transformacji ustrojowej było bowiem przeprowadzenie zmian w sferze własnościowej. Ich istota wyrażała się w odstąpieniu od deklarowanej na gruncie ówczesnego prawodawstwa marksistowskiej koncepcji własności zakładającej dywersyfikację własności i środków jej ochrony na rzecz jednolitego pojęcia własności oraz rezygnacji ze zróżnicowania pod względem podmiotowym przysługujących właścicielowi środków ochrony jego prawa. W tym właśnie modelu własności ustawodawca upatrywał bowiem fundamentu dla nowo kształtującego się ustroju społeczno-gospodarczego, opartego na idei społecznej gospodarki rynkowej. Zerwanie z marksistowską teorią własności, a co za tym idzie również z eksponowaną na tle ówczesnego prawodawstwa preferencją własności uspołecznionej, miało otworzyć drogę do rozwoju własności prywatnej nie tylko w odniesieniu do dóbr konsumpcyjnych, ale także środków produkcji. W swoich założeniach docelowy model gospodarki zakładał bowiem sprywatyzowanie całości gospodarki, z pozostawieniem jedynie niektórych, istotnych z punktu widzenia szeroko rozumianego bezpieczeństwa państwa, przedsiębiorstw państwowych zarządzanych w formach skomercjalizowanych. Zob. M. Bednarek, Koncepcja własności w dobie transformacji ustrojowej w Polsce, „Kwartalnik Prawa Prywatnego” 1993, z. 4, s. 448; S. Rudnicki, Własność nieruchomości, Warszawa 2008, s. 13-14; A. Stelmachowski, (w:) T. Dybowski (red.), System..., op. cit., s. 89 i nast.

15 L. Balcerowicz, Wieś, rolnictwo, wolny rynek. Rozszerzony tekst wykładu prof. L. Balcerowicza, wygłoszonego 18 marca 1993 r. w Szkole Głównej Gospodarstwa Wiejskiego w Warszawie, Warszawa 1993.

16 W. Ciechomski, Interwencjonizm państwowy w rolnictwie i obrocie rolnym, Poznań 1997, s. 5; A. Woś, Interwencjonizm państwowy i globalizacja w polityce rolnej, „Zagadnienia Ekonomiki Rolnej” 2005, nr 4, s. 6; J.F.N. Swi- 
ście to wynikało z postrzegania rolnictwa jako szczególnego obszaru działalności wytwórczej człowieka, przede wszystkim ze względu na specyficzne uwarunkowania gospodarcze oraz silne oddziaływanie w jego obrębie wartości ogólnospołecznych ${ }^{17}$. W konsekwencji akcentowano konieczność modyfikacji istniejących lub wprowadzania odrębnych rozwiązań dotyczących rolnictwa w stopniu pozwalającym na skuteczne rozwiązywanie problemów związanych z funkcjonowaniem sektora rolnego oraz wspierających jego zrównoważony rozwój ${ }^{18}$. Znaczącym jest, że przy akceptacji tego wyjściowego założenia regulacyjnego wśród przedstawicieli doktryny zarysowały się różnice co do metody i zakresu kreowanej odrębności regulacji prawnorolnej. Rozbieżności w tym zakresie dotyczyły między innymi kwestii fundamentalnych, czy w celu poprawy struktury agrarnej stosować należy instrumenty cywilnoprawne czy też publicznoprawne.

Wśród możliwych do zastosowania ujęć koncepcyjnych ustawodawca zdecydował się oprzeć mechanizm oddziaływania strukturalnego na instrumentach o charakterze prywatnoprawnym. Odzwierciedleniem takiego podejścia jest ustawa z dnia 11 marca 2003 r. o kształtowaniu ustroju rolnego ${ }^{19}$. Pomimo jednoznacznego eksponowania w swojej treści dążeń do wzmocnienia struktury agrarnej polskiego rolnictwa, ustawa ta nie spełnia wiązanych z nią zadań. Wśród przedstawicieli doktryny prawa rolnego ${ }^{20}$ oraz praktyków ${ }^{21}$ podnoszone są liczne mankamenty dotyczące

nner, Political Economy of Agricultural and Food Policies: Recent Contributions, New Insights, and Areas for Futher Research, Applied Economic Perspectives and Policy 2010, v. 32, nr 1, s. 36.

17 J. Wilkin, Rolnictwo a społeczeństwo - ewolucja funkcji i relacji, (w:) A. Rosner (red.), Uwarunkowania i kierunki przemian społeczno-gospodarczych na obszarach wiejskich, Warszawa 2005, s. 22.

18 Zob. szerzej na temat zrównoważonego rozwoju rolnictwa: A. Sadowski, Gospodarstwo rolne a koncepcja zrównoważonego rozwoju obszarów wiejskich, JARD 2009, z. 2, s. 170; M. Maciejczak, Rolnictwo i obszary wiejskie źródłem dóbr publicznych - przegląd literatury, „Zeszyty Naukowe Szkoły Głównej Gospodarstwa Wiejskiego w Warszawie. Ekonomika i Organizacji Gospodarki Żywnościowej” 2009, nr 75, s. 121; J. Wilkin, Uwarunkowania rozwoju polskiego rolnictwa w kontekście europejskim i globalnym. Referat przygotowany na VIII Kongres Ekonomistów Polskich „Polska w gospodarce światowej - szanse i zagrożenia rozwoju” Warszawa, 29 listopada 2007 r., s. 17-18 - opracowanie dostępne na stronie internetowej: www.pte.pl/pliki/0/247/pte-kongreswilkin.doc (dostęp: 7.10.2016)

19 Tekst jedn. Dz.U. z 2012 r. poz. 803 ze zm.

20 Por. np. S. Prutis, Kształtowanie ustroju rolnego - próba nowej regulacji ustawowej, „Przegląd Legislacyjny” 2005, t. V, s. 168 i nast.; A. Lichorowicz, Instrumenty oddziaływania na strukturę gruntową Polski w ustawie z dnia 11 kwietnia 2003 r. o kształtowaniu ustroju rolnego, „Kwartalnik Prawa Prywatnego” 2004, z. 2, s. 385 i nast.; A. Lichorowicz, Regulacja obrotu gruntami rolnymi według ustawy z 11 kwietnia 2003 r. na tle ustawodawstwa agrarnego Europy Zachodniej, „Przegląd Legislacyjny” 2004 nr 3, s. 11 i nast.; Z. Truszkiewicz, Przeniesienie własności nieruchomości rolnej w świetle ustawy o kształtowaniu ustroju rolnego. Część I, „Rejent” 2003, nr 9, s. 48 i nast., L. Błądek, Niektóre rozważania na temat ustawy z dnia 11 kwietnia 2003 r. o kształtowaniu ustroju rolnego, „Rejent” 2003, nr 9, s. 140 i nast.; D. Łobos-Kotowska, Ochrona gospodarstwa rodzinnego w procesie zbywania nieruchomości rolnych przez Agencję Nieruchomości, (w:) K. Skotnicki, K. Winiarski (red.), Własność i jej ograniczenia..., op. cit., s. 133, T. Kurowska, Ochrona gospodarstwa rodzinnego - uwagi de lege lata i de lege ferenda, „Studia luridica Agraria” 2010, T. VII, s. 21 i nast., E. Klat-Górska, Ograniczenia w nabywaniu własności nieruchomości rolnych według ustawy o kształtowaniu ustroju rolnego (cz. II), „Rejent” 2004, nr 6, s. 86; J. Matys, Ustawa o kształtowaniu ustroju rolnego - uwagi ogólne, „Studia luridica Agraria” 2015, T. XII, s. 199 i nast.; P. Czechowski, P. Wieczorkiewicz, Problemy ingerencji prawnej w swobodę obrotu nieruchomościami rolnymi w ustawie o kształtowaniu ustroju rolnego i jej wpływ na interpretację ustawodawstwa krajowego, „Studia luridica Agraria" 2005, nr 5, s. 39 i nast.

21 Na ten aspekt wprost wskazuje J. Matys, Ustawa o kształtowaniu ustroju..., op. cit., s. 200; Gniewek, Obowiązki notariusza w świetle współczesnych ograniczeń obrotu nieruchomościami rolnymi, (w:) E. Gniewek (red.), Zawieranie i wykonywanie umów. Wybrane zagadnienia, Wrocław 2004, s. 29 i nast.; T. Ciodyk, T. Zagórki, 
tego aktu prawnego. Pod względem merytorycznym podnoszone zarzuty mają charakter zasadniczy, gdyż odwołują się one do ratio przyjętej ustawy. Wskazuje się między innymi na brak dostosowania wprowadzanych instrumentów prawnych wobec zakładanych celów ustawy (brak adekwatności pomiędzy przyjmowanymi celami ustawy a jej rzeczywistym oddziaływaniem), słabość w zastosowaniu techniki legislacyjnej, wyrażająca się w nieprecyzyjnej siatce pojęciowejej ${ }^{22}$ oraz zastrzeżenia co do zgodności ustawy z Konstytucją $\mathrm{RP}^{23}$ i prawem unijnym ${ }^{24}$. Dla niektórych przedstawicieli doktryny stopień dostrzeganych wad ustawy z 2003 r. był na tyle istotny, że wprost wskazywano na konieczność dokonania zasadniczych zmian normatywnych, które nie będą sprowadzać się do nowelizacji tego aktu prawnego, lecz stanowić będą podstawę uchwalenia nowej ustawy dotyczącej kształtowania ustroju rol$\operatorname{nego~}^{25}$.

Powyższe zarzuty w pełni oddają istotę zastrzeżeń, jakie można zgłosić wobec ustawy o kształtowaniu ustroju rolnego. Podkreślenia wymaga, że pomimo licznych jej nowelizacji ustawodawca nie zdecydował się na zasadnicze zmiany przyjętych rozwiązań. Taki stan rzeczy na swoje źródło w złożonym kontekście uwarunkowań politycznych. Po pierwsze, wynika on z braku wypracowania jednolitej i aprobowanej przez wszystkie siły polityczne koncepcji rozwoju rolnictwa, która pozwalałaby na urzeczywistnienie konstytucyjnej idei gospodarstwa rodzinnego (art. 23 Konstytucji RP). Po drugie, z traktowania kwestii rolnej jako zagadnienia służącego przede wszystkim realizacji doraźnych celów politycznych. Nie jest przypadkiem, że problemy polskiej wsi i rolnictwa „odżywają” ze szczególnym natężeniem w okresie wyborczym i postrzegane są przede wszystkim jako źródło generowania kapitału politycznego. W konsekwencji podejmowane działania normatywne często nastawione są na realizację partykularnych interesów grup wpływu, nie zawsze przy tym równoważnych z zadaniami służącymi reformie polskiego rolnictwa. Po trzecie, można wskazać na występującą tendencję do niepodejmowania działań służących uwzględnianiu zasadniczych uwarunkowań dotyczących funkcjonowania rolnictwa. Kwestia niechęci prawodawcy do wprowadzania zmian w istniejącym status quo nie dotyczy wyłącznie zagadnień związanych z obrotem nieruchomościami rolnymi.

P. Iwaszkiewicz, Ustawa o kształtowaniu ustroju rolnego w praktyce, „Studia luridica Agraria” 2005, T. IV, s. 143 i nast.

22 A. Lichorowicz, Regulacja obrotu gruntami rolnymi..., op. cit., s. 9 i nast.

23 Konstytucja Rzeczpospolitej Polskiej z 2 kwietnia 1997 r. (Dz.U. z 1997 r. Nr 78, poz. 483 ze zm.). Dostrzegane wątpliwości stanowiły także kanwę dla analizy podjętej przez Trybunał Konstytucyjny w wyroku z dnia 18 marca 2010 r., sygn. akt K 8/08, publ. OTK-A 2010, nr 3, poz. 23.

24 A. Lichorowicz, Regulacja obrotu gruntami rolnymi..., op. cit., s. 9 i nast.; M. Mataczyński, W kwestii zgodności ustawy z dnia 11 kwietnia 2003 r. o kształtowaniu ustroju rolnego z prawem europejskim w świetle orzecznictwa Europejskiego Trybunału Sprawiedliwości, „Rejent” 2004, nr 9, s. 73 i nast.

25 W tym względzie charakterystyczne są wypowiedzi prof. S. Prutisa, który wskazywał na konieczność opracowania nowej regulacji ustawowej dotyczącej ustroju rolnego. Wprost wskazywał, że w krótkim okresie obowiązywania ustawy da się wyróżnić w tym akcie prawnym błędy, nieścisłości, mankamenty na tyle poważne, że nie można ich poprawić w drodze nowelizacji. Jednocześnie podkreślał on, że praktyczna działalność Agencji Nieruchomości Rolnych w oparciu o przyjęte mechanizmy nie zapewnia realizacji zasad kształtowania ustroju rolnego. Por. S. Prutis, Kształtowanie ustroju rolnego..., op. cit., s. 168 i nast. 
W istocie sprowadza się ona do całego obszaru regulacji rolnej. Tytułem przykładu wystarczy wskazać na brak wprowadzenia regulacji prawnej dotyczącej tak istotnej - z perspektywy społeczności wiejskiej - kwestii, jak zagadnienie ubezpieczenia społecznego rolników uwzględniające orzeczenie Trybunału Konstytucyjnego. Nadal bowiem, pomimo stwierdzenia przez Trybunał niezgodności z konstytucją przepisów dotyczących ubezpieczenia społecznego rolników z $\mathrm{KRUS}^{26}$, nie wprowadzono stosownych rozwiązań, które uporządkowałyby istniejącą w tym względzie lukę legislacyjną. Nadmienić w tym miejscu należy, że brak determinacji w podejmowaniu działań reformujących wyznaczone ramy prawne dla funkcjonowania sektora rolnego jest zjawiskiem występującym w większości współczesnych gospodarek wolnorynkowych opartych na interwencjonistycznym i protekcjonistycznym podejściu do funkcjonowania sektora rolnego. W naukach politycznych wprost wskazuje się, że taki stan rzeczy kreuje rolnicze państwo dobrobytu (ang. agricultural welfare state), co wiąże się z równoczesną presją polityczną ze strony rolników i społeczności wiejskiej, dążącą do utrzymania istniejących uwarunkowań przypisywanych dla tego obszaru aktywności wytwórczej człowieka ${ }^{27}$.

W Polsce w kwestii kształtowania struktury agrarnej mamy do czynienia ze stanem dalekim od realnego oddziaływania na tę sferę działalności rolniczej. Obowiązująca ustawa o kształtowaniu ustroju rolnego, wbrew wyrażanemu jednoznacznie w tytule tego aktu oddziaływaniu na ustrój rolny, realizuje te zamierzenia w sposób na wskroś niedoskonały. Koncepcja normatywna zakładająca kluczową rolę Agencji Nieruchomości Rolnych Skarbu Państwa, jako dysponenta zasobu nieruchomości rolnych i podmiotu stymulującego właściwy kierunek rozwoju struktur rodzimego rolnictwa (unikanie rozdrobnienia gospodarstw rolnych, zapobieganie procesom zbytniej koncentracji nieruchomości rolnych oraz zapewnienie prowadzenia gospodarstw rolnych przez osoby posiadające odpowiednie kwalifikacje zawodowe) nie przyniosła oczekiwanych rezultatów ${ }^{28}$. Wprawdzie, jak pokazują dane statystyczne, występuje tendencja do powiększania się areału gospodarstw rolnych (w 2002 r. średnia wielkość gospodarstwa rolnego wynosiła 5,8 ha, w 2011 r. - 9,1 ha, w 2013 r. - 10,2 ha). Nadal jednak ponad połowa gospodarstw w Polsce użytkuje nie więcej niż 5 ha użytków rolnych, a 3/4 gospodarstw mniej niż 10 ha. ${ }^{29}$ Dane te pokazują, że nadal w polskim rolnictwie dominują gospodarstwa o niskim areale uprawnym, co oznacza ograniczone zdolności produkcyjne i małą ich konkurencyjność na rynku ${ }^{30}$. Ponad 10-letnia działalność ANR nie zmieniła zatem w sposób znaczący uwarunkowań strukturalnych polskiego rolnictwa. Jak trafnie wskazuje

26 Wyrok TK z dnia 26 października 2010 r., sygn. akt K 58/07, publ. OTK-A 2010, nr 8, poz. 80.

27 K. Gorlach, Socjologia obszarów wiejskich. Problemy i perspektywy, Warszawa 2004, s. 14-15.

28 Por. P. Czechowski, A. Niewiadomski, Propozycje reformy rozwiązań instytucjonalnych dotyczących państwowych nieruchomości rolnych, „Studia luridica Agraria” 2011, t. IX, s. 22.

29 J. Matys, Ustawa o kształtowaniu ustroju..., op. cit., s. 202-203.

30 Tamże, s. 203. 
się w literaturze, już w momencie wyjściowym możliwości skutecznego działania ANR były znacząco ograniczone ze względu na przyjęcie zasady samofinansowania jej działalności. W konsekwencji środki finansowe, jakie ANR mogła przeznaczyć na realizację jej celów ustawowych, nie były (i nadal nie są) adekwatne wobec jej rzeczywistych potrzeb. W praktyce oznacza to istotne ograniczenie możliwości wykorzystania przez ANR kompetencji wynikających z prawa pierwokupu w przypadkach, gdy zbycie nieruchomości rolnej będzie negatywnie oddziaływało na kształtowanie się struktury agrarnej.

\section{4.}

Ustawa z dnia 14 kwietnia 2016 r. o wstrzymaniu sprzedaży nieruchomości Państwowego Zasobu Nieruchomości Rolnych Skarbu Państwa oraz zmianie niektórych innych ustaw ${ }^{31}$ stanowi kolejny wyraz aktywności legislacyjnej związanej z kształtowaniem struktury agrarnej. Utrzymuje dotychczasowy model oddziaływania państwa na strukturę agrarną. In meritum odwołuje się ona zatem do problematyki obrotu nieruchomościami rolnymi, w której nadal upatruje się zasadniczego obszaru oddziaływania strukturalnego. Ustawa zachowuje również zasadnicze założenia dotyczące mechanizmu oddziaływania na strukturę agrarną, przyjęte w ustawie z 2003 r. o kształtowaniu ustroju rolnego. Wynikające z niej modyfikacje w zakresie uwarunkowań dotyczących obrotu nieruchomościami rolnymi mają jednak na tyle istotne odniesienia praktyczne, iż warto poddać je analizie w niniejszym opracowaniu.

Z uzasadnienia do projektu omawianej ustawy wynika, iż podjęta działalność legislacyjna nastawiona jest przede wszystkim na ochronę polskiej ziemi rolnej przed spekulacyjnym jej nabywaniem przez podmioty zagraniczne, które - jak wprost wskazuje ustawodawca - nie gwarantują zgodnego z interesem społecznym wykorzystania nabytej ziemi na cele rolnicze ${ }^{32}$. W zjawisku tym dostrzega bowiem zagrożenia dla bezpieczeństwa żywnościowego i zapewnienia właściwego rozwoju strukturalnego polskiego rolnictwa. Tym samym zachodzi konieczność wprowadzenia stosownych instrumentów ochronnych pozwalających na unikanie sytuacji, w których nieruchomości rolne nabywane są w celach niezwiązanych z działalnością rolniczą. Wskazać także należy, że źródeł wskazanych powyżej zagrożeń ustawodawca dopatruje się przede wszystkim w skutkach wygaśnięcia z dniem 1 maja 2016 r. okresu przejściowego, w którym to - zgodnie z art. 4.2. XII załącznika do Traktatu Akcesyjnego - wyłączono możliwość nabywania nieruchomości rolnych przez obywateli państw członkowskich UE. W uzasadnieniu podkreśla się, że pomimo upływu tzw. okresu ochronnego nadal występują istotne dysproporcje w war- 
tości nieruchomości rolnych oraz wysokości uzyskiwanych dochodów przez obywateli polskich względem pozostałych państw UE (przede wszystkim tzw. starej UE). W konsekwencji obywatele państw członkowskich UE będą posiadali przewagę ekonomiczną wobec polskiego rolnika przy nabywaniu nieruchomości ${ }^{33}$. Nabywanie przez nich nieruchomości rolnych może być przy tym traktowane wyłącznie jako forma lokaty kapitału i nie będzie wiązało się z prowadzeniem działalności rolniczej. Takie implikacje mają zaś w sposób niekorzystny przekładać się na uwarunkowania strukturalne polskiego sektora rolnego.

Zarysowana powyżej motywacja stanowiła podstawę do wprowadzenia rozwiązań zakładających: 1) czasowe wyłączenie sprzedaży nieruchomości rolnych lub ich części wchodzących w skład Zasobu Własności Rolnej Skarbu Państwa; 2) ograniczenia podmiotowe przy przenoszeniu własności nieruchomości rolnych;3) zwiększenie kontroli obrotu nieruchomościami rolnymi oraz umocnienie pozycji ANR przy przenoszeniu ich własności. Znaczącym jest także, że jakkolwiek zasadnicze zagrożenia ustawodawca dostrzega $w$ nabywaniu nieruchomości przez podmioty pochodzące z państw obcych, to rozwiązania zawarte w ustawie dotyczą również obywateli polskich. Przyjęcie takiego zakresu podmiotowego ustawy uzasadnia się dążeniem do zapewnienia skuteczności rozwiązań stanowionych w tym akcie poprzez unikanie ich obchodzenia w wyniku czynności prawnych dokonywanych przez obywateli polskich (tzw. słupów) na rzecz obywateli państw obcych ${ }^{34}$.

\section{5.}

Przed przystąpieniem do analizy niektórych rozwiązań stanowionych w ustawie z dnia 14 kwietnia 2016 r. o wstrzymaniu sprzedaży nieruchomości z Zasobu Własności Rolnej Skarbu Państwa należy podkreślić istnienie potrzeby i zasadności podejmowania inicjatyw legislacyjnych zmierzających do wsparcia strukturalnego polskiego rolnictwa. Słabości ekonomiczne ujawniające się w tym obszarze gospodarki oraz związane z nimi istotne odniesienia społeczne, które nie znajdują bezpośredniego przełożenia w mechanizmie rynkowym, wymagają podejmowania przez państwo działań pozwalających na ochronę tego sektora oraz stymulujących jego rozwój.

Podkreślić trzeba, że oddziaływanie państwa na kształt struktury agrarnej koncentruje się w głównej mierze na ingerencji w sferę uprawnień właścicielskich rolników. W ujęciu prawodawstwa krajowego dominują bowiem te instrumenty wspierania potencjału produkcyjnego gospodarstw, które odwołują się wprost do czynnika niezbędnego przy produkcji rolnej, jakim jest ziemia (nieruchomość rolna) oraz zakresu władztwa realizowanego przez rolnika w stosunku do tego przedmiotu. Od- 
działywanie na struktury rolne zatem $\mathrm{w}$ swojej istocie opiera się na poszukiwaniu równowagi pomiędzy przyjmowaną przez prawodawcę preferencją $\mathrm{w}$ zakresie kształtowania tych struktur (w szerszym zaś ujęciu konstytuującą uwarunkowania ustroju rolnego) a koncepcją własności i wyznaczaną w jej obrębie sferą władztwa jednostki nad rzeczą. Wymaga to zatem tworzenia wyłącznie takich rozwiązań, które będą niezbędne dla realizacji zakładanych celów strukturalnych. Przekłada się to także na postrzeganie skuteczności stanowionych rozwiązań, ta zaś - o czym już wspomniano - stanowi istotną słabość współczesnej regulacji prawnorolnej.

Niestety, ustawa z dnia 14 kwietnia 2016 r. o wstrzymaniu sprzedaży nieruchomości Zasobu Własności Rolnej Skarbu Państwa powiela wiele wad, krytykowanych w dotychczasowej regulacji. Wskazać można szereg zastrzeżeń związanych ze skutecznością i adekwatnością stanowionych przez nią rozwiązań dla ochrony strukturalnej polskiego rolnictwa.

Trzeba podkreślić, że ustawa przewiduje wstrzymanie sprzedaży nieruchomości Zasobu Własności Rolnej Skarbu Państwa przez okres 5 lat od wejścia jej w życie (art. 1 ustawy). Obrót takimi nieruchomościami dopuszcza się jedynie wyjątkowo w odniesieniu do niektórych kategorii nieruchomości rolnych (art. 2 ust. 1). Przewiduje się również sprzedaż nieruchomości lub ich części, innych niż objęte wyłączeniem z art. 2 ust. 1 ustawy, na podstawie decyzji Ministra Rolnictwa wydanej na wniosek Prezesa Agencji Nieruchomości Rolnych, jeżeli za dopuszczeniem do sprzedaży przemawiają względy społeczno-gospodarcze. Wprowadzone rozwiązanie, jak wskazuje się w uzasadnieniu ustawy, ma służyć ochronie „,polskiej ziemi rolnej" przed jej wykupem przez podmioty zagraniczne, dla których nabywanie nieruchomości rolnych traktowane jest jako jedna z form lokaty kapitału. Znamienne jest przy tym, że źródła tak postrzeganej relacji na krajowym rynku nieruchomości rolnych upatruje się w niskiej, względem pozostałych państw członkowskich UE, dochodowości działalności rolniczej, co - w przekonaniu ustawodawcy - prowadzi do zmniejszenia ich zdolności konkurowania przy nabywaniu nieruchomości rolnych należących do Zasobu Własności Rolnej Skarbu Państwa. Pomimo takiego postrzegania motywów podjętych działań legislacyjnych, ustawodawca zdecydował się na wstrzymanie sprzedaży nieruchomości zasobu również w odniesieniu do obywateli RP (a w praktyce polskich rolników). Skutkiem wejścia w życie ustawy z dnia 14 kwietnia 2016 r. może być zatem istotne ograniczenie możliwości zwiększania zdolności produkcyjnych przez polskich rolników poprzez nabywanie nieruchomości należących do Zasobu Własności Rolnej Skarbu Państwa. W szerszym ujęciu przekłada się to także na ograniczenie możliwości zwiększania potencjału dochodowego polskiego sektora rolnego. Nabywanie nieruchomości z Zasobu Własności Rolnej Skarbu Państwa stanowiło bowiem dotychczas jedno z zasadniczych źródeł powiększania areału uprawnego polskich gospodarstw rolnych, a tym samym wzmacniania strukturalnego rodzimego sektora rolnego. Rozwiązania wprowadzo- 
ne w ustawie mogą zatem prowadzić do zahamowania dostrzeganego trendu, wskazującego na niewielką, stopniową poprawę struktury powierzchniowej polskich gospodarstw rolnych. Wprawdzie ustawa ta dopuszcza możliwość nabycia nieruchomości w okresie wyłączenia obrotu na podstawie stosownej decyzji Ministra Rolnictwa, to jednak jej wydanie determinowane jest przez kryterium ,wzzględów społeczno-gospodarczych" (art. 2 ust. 2 ustawy). Oznacza to znaczącą relatywizację ocen przy wydawaniu decyzji przez Ministra Rolnictwa i w istocie uzależnienie uzyskania zgody na nabycie nieruchomości z Zasobu Własności Rolnej Skarbu Państwa od przyjmowanej pragmatyki działania Ministra Rolnictwa w kwestii oceny zgłaszanych wniosków, która - co należy podkreślić - pozbawiona jest odniesień do obiektywnych kryteriów oceny. Znamiennym jest, że wydanie stosownej decyzji uzależnione jest od wystąpienia z wnioskiem przez Prezesa Agencji Nieruchomości Rolnych i także tutaj ustawodawca nie wprowadza żadnych obiektywnych przesłanek wskazujących na podjęcie stosownej aktywności. W praktyce mechanizm ten nie tylko będzie zniechęcał rolników do podejmowania działań inwestycyjnych z wykorzystaniem nieruchomości należących do Zasobu Własności Rolnej Skarbu Państwa, ale jednocześnie stwarza szerokie pole do nadużyć ze względu na brak wprowadzenia jednoznacznych kryteriów uzasadniających dopuszczenie sprzedaży nieruchomości na podstawie decyzji Ministra Rolnictwa.

Zastrzeżenia zgłosić także należy do wprowadzonych ustawą zmian w ustawie z dnia 11 kwietnia 2003 r. o kształtowaniu ustroju rolnego (w skrócie: u.k.u.r.) m.in. w zakresie dotyczącym możliwości nabywania przez spółki prawa handlowego nieruchomości rolnych; przyznania Agencji Nieruchomości Rolnych prawa pierwokupu udziałów i akcji w spółkach prawa handlowego (art. 3a u.k.u.r.) oraz nabycia przez Agencję Nieruchomości Rolnych nieruchomości rolnej stanowiącej własność spółki osobowej w sytuacji zmian w składzie osobowym spółki.

W następstwie nowelizacji u.k.u.r. ograniczono możliwość nabycia nieruchomości rolnych wyłącznie przez rolnika indywidualnego (art. 2a ust.1 u.k.u.r.), tj. osobę fizyczną będącą właścicielem, użytkownikiem wieczystym, samoistnym posiadaczem lub dzierżawcą nieruchomości rolnych, których łączna powierzchnia użytków rolnych nie przekracza 300 ha, posiadającą kwalifikacje rolnicze oraz co najmniej od 5 lat zamieszkałą w gminie, na obszarze której jest położona jedna z nieruchomości rolnych wchodzących w skład gospodarstwa rolnego i prowadzącą przez ten okres osobiście to gospodarstwo (art. 6 ust. 1 u.k.u.r.). De lege lata oznacza to, że nabycie nieruchomości rolnej nie może nastąpić na rzecz spółki prawa handlowego nawet wówczas, gdy zasadniczy przedmiot jej działalności gospodarczej stanowi produkcja rolna. Takie podejście ustawodawcy stanowi nieuzasadnione we współczesnych realiach gospodarczych zawężenie dopuszczalnych form prawnych prowadzenia działalności rolniczej. W wymiarze gospodarczym oznacza to: 1) wykluczenie możliwości zwiększania zdolności produkcyjnych poprzez na- 
bywanie nowych nieruchomości rolnych przez istniejące już spółki handlowe, które prowadzą działalność rolniczą; 2) wyłączenie posługiwania się formą spółki handlowej dla podejmowania działalności rolniczej, a tym samym pozbawienie możliwości wykorzystania tej właśnie formy prawnej dla minimalizowania ryzyka gospodarczego przy prowadzeniu działalności rolniczej.

Wątpliwości budzi również przyznanie Agencji Nieruchomości Rolnych prawa pierwokupu udziałów lub akcji w spółkach kapitałowych, w skład majątku których wchodzą nieruchomości rolne (art. 3a u.k.u.r.). Mianowicie realizacja prawa pierwokupu przez Agencję Nieruchomości Rolnych dotyczyć będzie każdej czynności zbycia udziałów lub akcji w każdej spółce kapitałowej będącej właścicielem nieruchomości rolnej, bez względu na stopień odniesienia wartości nieruchomości do wartości całego majątku spółki. W konsekwencji, w świetle art. 3a u.k.u.r. agencja będzie mogła nabyć udziały lub akcje w spółce kapitałowej, której główny przedmiot działalności nie jest związany z produkcją rolną, a nieruchomość rolna ma marginalne znaczenie z punktu widzenia wartości majątku spółki. Jednocześnie w ustawie nie wprowadza się żadnych rozwiązań, które pozwalałyby na związanie wykonywania prawa pierwokupu z wartością nieruchomości rolnej. Tym samym wykonanie prawa pierwokupu przez Agencję Nieruchomości Rolnych może następować przy zbywaniu udziałów lub akcji, których wartość (stanowiąca odzwierciedlenie stopnia partycypacji w majątku spółki) znacząco przewyższa wartość nieruchomości rolnej stanowiącej własność spółki. Artykuł 3a u.k.u.r. istotnie wzmacnia zatem rolę Agencji Nieruchomości Rolnych w sferze obrotu udziałami lub akcjami spółek kapitałowych. Realizacja tak szeroko ujętego uprawnienia Agencji Nieruchomości Rolnych skutkować może nieuzasadnioną względami merytorycznymi ingerencją podmiotu państwowego w obszarze działalności gospodarczej prowadzonej przez podmioty prywatne w ramach formy spółki kapitałowej. Bez względu bowiem na stopień odzwierciedlenia wartości nieruchomości rolnej w majątku spółki na podstawie art. 3a u.k.r.u. agencja, w oparciu o przysługujące jej prawo pierwokupu, będzie mogła nabywać udziały lub akcje spółek kapitałowych, a tym samym stawać się uczestnikiem jej struktury korporacyjnej oraz wykonywać wynikające z udziałów lub akcji uprawnienia o charakterze majątkowym i korporacyjnym. Z perspektywy kontrahentów zainteresowanych zbyciem udziałów lub akcji, dokonanie takiej czynności będzie obciążone znacznym ryzykiem gospodarczym ze względu na możliwość skorzystania przez agencję z prawa pierwokupu. Wynikające $\mathrm{z}$ art. 3a u.k.u.r. implikacje mają zatem znaczące odniesienia praktyczne. Dla ochrony interesów kontrahentów każdoczesna transakcja zbycia udziałów lub akcji będzie wymagała dokonania uprzednich ustaleń co do tego, czy w skład majątku spółki, której udziały lub akcje są zbywane, nie wchodzi nieruchomość rolna, a tym samym czy Agencji Nieruchomości Rolnych nie przysługuje prawo pierwokupu. Trudności praktyczne potęguje fakt, iż ze względu na brak ujęcia planami zagospodarowania przestrzennego całości 
obszaru kraju, mogą występować niejasności w kwestii kwalifikacji konkretnej nieruchomości stanowiącej własność spółki kapitałowej jako nieruchomości rolnej. Poczynienie zaś stosownych ustaleń przez strony na etapie zbywania udziałów lub akcji jest o tyle istotne, że dokonanie tej czynności z pominięciem uprawnień Agencji Nieruchomości Rolnych wynikających z art. 3a u.k.u.r. obciążone jest sankcją nieważności czynności prawnej (art. $559 \S 2 \mathrm{w}$ zw. z art. 3a ust. 4 u.k.u.r.).

Odnieść się także należy do zmian wprowadzonych przez ustawę z dnia 14 kwietnia 2016 r. w przepisach kodeksu cywilnego. Tu również, powołując się na potrzebę ochrony struktury gospodarstwa rolnego, wprowadzono istotne modyfikacje dotyczące nieruchomości rolnych. Ustawą znowelizowano między innymi art. 173 kc. i wyłączono możliwość zasiedzenia nieruchomości rolnej przez podmiot nieposiadający statusu rolnika indywidualnego (art. $173 \S 3 \mathrm{kc}$.). W odniesieniu do tego rozwiązania znaczącym jest, iż podważa ono założenia konstrukcyjne właściwe dla instytucji zasiedzenia. Instytucja ta służy bowiem usankcjonowaniu stanów faktycznych, w których podmiot niebędący właścicielem realizuje w sposób długotrwały swoje uprawnienia do rzeczy jako właściciel. Nabycie własności przez podmiot zasiadujący jest przy tym konsekwencją braku aktywności w zakresie realizacji uprawnień właścicielskich przez właściciela rzeczy (nieruchomości). Przy takim postrzeganiu instytucji zasiedzenia trudno uznać za słuszne wyłączenie możliwości zasiedzenia nieruchomości rolnej, gdy właściciel tej nieruchomości w sposób długotrwały nie wykonuje władztwa nad rzeczą. Tym samym rozwiązanie to w żaden sposób nie chroni trwałości produkcyjnej gospodarstwa rolnego, gdyż zasiedzenie następuje w odniesieniu do tych nieruchomości, względem których nie są wykonywane przez właściciela uprawnienia władcze, czego przejawem jest m.in. brak rolniczego wykorzystania gruntu (ius possidendi). Wskazać również należy na występującą niewspółmierność pozycji przy stosowaniu instytucji zasiedzenia. Rolnik indywidualny może bowiem zasiedzieć każdą nieruchomość bez względu na jej charakter (i ewentualne późniejsze jej przeznaczenie). Natomiast osoba nieposiadająca statusu rolnika indywidualnego może zasiedzieć jedynie te nieruchomości, które nie mają charakteru rolnego. Występujące rozróżnienie, co wskazano powyżej, nie znajduje jednak żadnego przełożenia na zapewnienie właściwego ukształtowania struktury agrarnej w Polsce.

\section{6.}

Zarysowane powyżej uwagi dotyczące regulacji prawnej w zakresie kształtowania struktury rolnej naszego rolnictwa wskazują na istotne wady w tej materii. Zasadnicze problemy wynikają z braku ukształtowania jednolitego modelu oddziaływania na strukturę agrarną i podporządkowania tej sfery regulacji doraźnym celom normatywnym. Konsekwencją zaś takiego stanu rzeczy są rozwiązania prawne pozbawione możliwości efektywnego wpływania na poprawę struktury rodzime- 
go sektora rolnego oraz wykazujące znaczące wady legislacyjne. Niestety, ustawa z dnia 14 kwietnia 2016 r. powiela sygnalizowane niedoskonałości. We wskazanych powyżej obszarach, wynikający z niej rygoryzm w zakresie obrotu nieruchomościami rolnymi, można postrzegać jako czynnik rzutujący na zahamowanie właściwego kształtowania stosunków własnościowych na polskiej wsi. Wzmocnienie zaś roli Agencji Nieruchomości Rolnych w mechanizmie obrotu nieruchomościami rolnymi, przy utrzymaniu dotychczasowego modelu jej funkcjonowania, stwarza istotne obawy co do możliwości zapewnienia warunków umożliwiających skuteczną realizację przyznanych jej uprawnień. Podkreślić też należy, że podejmowane działania ochronne powinny uwzględniać implikacje wynikające z ingerencji w konstytucyjnie chronione wartości, takie jak własność czy swoboda działalności gospodarczej. Z tego względu za zbyt rygorystyczne należy uznać między innymi wskazane powyżej rozwiązania dotyczące realizacji prawa pierwokupu udziałów lub akcji w spółkach kapitałowych, których składnikiem majątku jest nieruchomość rolna. 
Wpływ ustawy z dnia 14 kwietnia 2016 r. o wstrzymaniu sprzedaży nieruchomości...

THE IMPACT OF THE LAW DATED 14 APRIL 2016 ON SUSPENTION OF THE SALE OF THE AGRICULTURAL REAL ESTATE FROM THE STATE RESERVE ON SHAPING OF AGRARIAN SYSTEM - FEW REFLECTIONS

Keywords: agrarian system, agricultural real estate, agricultural law, agricultural sector

Shaping the Agrarian System is one of the basic topics of the Polish Agricultural Law. The main problem here is to define a proper model of ownership relations in the agricultural sector and principles of the real estate trading. These issues are relevant for both economic and political relations. In economy the influence the real capability of the agricultural sector as well as the standard of living of the agricultural society. In the politics they are treated as the instruments assuring the food security for all the citizens and in the international relations food sovereignity.

The article presents, against the historical background, the solutions provided in the recently adopted law, the main purpose of which was to restrict the possibility of acquiring the agricultural real estate by foreigners. The new law provides a ban for the transfer of state owned agricultural real estate not only to foreigners but also to Polish citizens who are not farmers. It also provides certain other restrictions on this area.

\section{Bibliografia:}

Balcerowicz L., Wieś, rolnictwo, wolny rynek. Rozszerzony tekst wykładu prof. L. Balcerowicza, wygłoszonego 18 marca 1993 r. w Szkole Głównej Gospodarstwa Wiejskiego w Warszawie, Warszawa 1993.

Bednarek M., Koncepcja własności w dobie transformacji ustrojowej w Polsce, „Kwartalnik Prawa Prywatnego" 1993, z. 4.

Bednarek M., Przemiany własności w Polsce. Podstawowe koncepcje i konstrukcje normatywne, Warszawa 1994.

Bienkowski W., Problemy teorii rozwoju społecznego, Warszawa 1966.

Błądek L., Niektóre rozważania na temat ustawy z dnia 11 kwietnia 2003 r. o kształtowaniu ustroju rolnego, ,Rejent” 2003, nr 9.

Ciechomski W., Interwencjonizm państwowy w rolnictwie i obrocie rolnym, Poznań 1997.

Ciodyk T., Zagórki T., Iwaszkiewicz P., Ustawa o kształtowaniu ustroju rolnego w praktyce, „Studia Iuridica Agraria” 2005, T. IV.

Czechowski P., Opinia indywidualna członka Rady Legislacyjnej do projektu ustawy o kształtowaniu ustroju rolnego państwa oraz zmianie niektórych innych ustaw, „Przegląd Legislacyjny” 2003, $\mathrm{nr} 2$.

Czechowski P., Niewiadomski A., Propozycje reformy rozwiązań instytucjonalnych dotyczących państwowych nieruchomości rolnych, „Studia Iuridica Agraria” 2011, T. IX. 
Czechowski P., Wieczorkiewicz P., Problemy ingerencji prawnej w swobodę obrotu nieruchomościami rolnymi w ustawie o kształtowaniu ustroju rolnego i jej wpływ na interpretację ustawodawstwa krajowego, „Studia Iuridica Agraria” 2005, T. 5.

Gniewek E., Obowiązki notariusza w świetle współczesnych ograniczeń obrotu nieruchomościami rolnymi, (w:) E. Gniewek (red.), Zawieranie i wykonywanie umów. Wybrane zagadnienia, Wrocław 2004.

Gorlach K., Socjologia obszarów wiejskich. Problemy i perspektywy, Warszawa 2004.

Gualtieri D., Right to Food, Food Security, and Food Aid Under International Law, or the Limits of a right-based approach, Future of Food: Journal on Food, „Agriculture and Society” 2013, v. 1, nr 2.

Haugen H.M., Food Sovereignty - An Appropriate Approach to Ensure the Right to Food?, „Nordic Journal of International Law” 2009, v. 78.

Hopkins R.F., Food security, policy options and the evolution of state responsibility, (w:) F. La Monde Tullis, W.L. Hollis (red.), Food, the state and international policy economy. Dilemmas of developing countries, Lincoln - London 1986.

Jabłońska-Bonca J., Własność - w labiryncie interdyscyplinarnych problemów. Kilka uwag wstępnych, (w:) J. Jabłońska-Bonca (red.), Krytyka prawa. Niezależne studium nad prawem. Tom I. Własność, Warszawa 2009.

Jurcewicz A., Problematyka prawna ustawy o kształtowaniu ustroju rolnego (na tle zarysu historycznego w sferze obrotu nieruchomościami rolnymi), „Wieś i Rolnictwo” 2006, nr 1.

Jurcewicz A., Popardowski P., Własność w ujęciu prawa polskiego i prawa UE, „Studia Iuridica Agraria" 2011, T. IX.

Jurcewicz A., Popardowski P., Własność w rolnictwie - ujęcie systemowe z perspektywy prawa krajowego i unijnego, „Studia Prawnicze” 2014, nr 1.

Jurcewicz W., Ewolucja regulacji prawnej dotyczącej gospodarowania gruntami rolnymi w latach 1944-1984, „Wieś i Rolnictwo” 1985, nr 1.

E. Klat-Górska, Ograniczenia w nabywaniu własności nieruchomości rolnych według ustawy o kształtowaniu ustroju rolnego (cz. II), „Rejent” 2004, nr 6.

Kołoszko-Chomentowska Z., Sieczko L., Gospodarstwo rodzinne jako podmiot w gospodarce narodowej, „Economics and Management” 2014, nr 1.

Korzycka-Iwanow M., Ochrona własności rolniczej w nawiązaniu do koncepcji własności rolniczej Profesora Andrzeja Stelmachowskiego, „Studia Iuridica Agraria” 2011, T. IX.

Kurowska T., Gospodarstwo rodzinne w świetle art. 23 Konstytucji RP, (w:) K. Skotnicki, K. Winiarski (red.), Własność i jej ograniczenia w prawie polskim. Materiały konferencyjne, Częstochowa 2004.

Kurowska T., Ochrona gospodarstwa rodzinnego - uwagi de lege lata i de lege ferenda, „Studia Iuridica Agraria" 2010, T. VII.

Kurowska T., Renesans własności rolniczej, „Przegląd Prawa Rolnego” 2014, nr 2.

Lichorowicz A., Szczególny porządek dziedziczenia gospodarstw rolnych w Polsce po orzeczeniu Trybunału Konstytucyjnego z 31.01.2001 r., „Rejent” 2001, nr 9, s. 88-89.

Lichorowicz A., Instrumenty oddziaływania na strukturę gruntową Polski w ustawie z dnia 11 kwietnia 2003 r. o kształtowaniu ustroju rolnego, ,Kwartalnik Prawa Prywatnego” 2004, z. 2.

Lichorowicz A., Regulacja obrotu gruntami rolnymi według ustawy z dnia 11 kwietnia 2003 r. na tle ustawodawstwa agrarnego Europy Zachodniej, „Przegląd Legislacyjny” 2004 nr 3. 
Łobos-Kotowska D., Ochrona gospodarstwa rodzinnego w procesie zbywania nieruchomości rolnych przez Agencję Nieruchomości, (w:) K. Skotnicki, K. Winiarski (red.), Własność i jej ograniczenia w prawie polskim. Materiały konferencyjne, Częstochowa 2004.

Maciejczak M., Rolnictwo i obszary wiejskie źródłem dóbr publicznych - przegląd literatury, „Zeszyty Naukowe Szkoły Głównej Gospodarstwa Wiejskiego w Warszawie. Ekonomika i Organizacji Gospodarki Żywnościowej” 2009, nr 75.

Mataczyński M., W kwestii zgodności ustawy z dnia 11 kwietnia 2003 r. o kształtowaniu ustroju rolnego z prawem europejskim w świetle orzecznictwa Europejskiego Trybunału Sprawiedliwości, ,Rejent” 2004, nr 9.

Matys J., Ustawa o kształtowaniu ustroju rolnego - uwagi ogólne, „Studia Iuridica Agraria” 2015, T. XII.

Mechlem K., Food Security and the Right to Food in the Discourse of the United Nations, „European Law Journal" 2004, v. 10, nr 2.

Michna W., Ewolucja rodzinnych gospodarstw rolnych na rzecz uzyskania odpowiedniej zdolności konkurencyjnej i samowystarczalności żywnościowej kraju, (w:) Gospodarstwa rodzinne podstawą europejskiego rolnictwa, Warszawa 2011.

Mitręga D., Ostrój I., Wpływ państwa na zmiany struktury własnościowej w warunkach gospodarki rynkowej, (w:) J. Żabińska (red.), Państwo w gospodarce rynkowej, Katowice 1992.

Poczta W., Szuba-Barańska E., Beba P., Czubak W., Strukturalna i ekonomiczna różnorodność a możliwości rozwoju gospodarstw rodzinnych w UE, „Wieś i Rolnictwo” 2015, nr 1.

Prus P., Współczesne problemy rolnictwa i obszarów wiejskich w Polsce, „Zeszyty Naukowe SGGW w Warszawie - Problemy Rolnictwa Światowego" 2008, t. 5.

Prutis S., Kształtowanie ustroju rolnego - próba nowej regulacji ustawowej, „Przegląd Legislacyjny” 2005 , t. V.

Prutis S., Własność rolnicza według Profesora Andrzeja Stelmachowskiego, (w:) P. Czechowski (red.), Prawo rolne, Warszawa 2013.

Prutis S., Zróżnicowanie własnościowe gospodarstw rolnych - synchronizacja pojęć, „Studia Iuridica Agraria" 2014, T. XII.

Rudnicki S., Własność nieruchomości, Warszawa 2008.

Sadowski A., Gospodarstwo rolne a koncepcja zrównoważonego rozwoju obszarów wiejskich, JARD 2009, z. 2.

Stefańska K., Gospodarstwo rodzinne jako element ustroju rolnego, „Studia Iuridica Agraria” 2004, T. III.

Swinner J.F.N., Political Economy of Agricultural and Food Policies: Recent Contributions, New Insights, and Areas for Futher Research, Applied Economic Perspectives and Policy 2010, v. 32, nr 1.

System prawa prywatnego. Prawo rzeczowe. Tom 3, Warszawa 2007.

Truszkiewicz Z., Przeniesienie własności nieruchomości rolnej w świetle ustawy o kształtowaniu ustroju rolnego. Część I, „Rejent” 2003, nr 9.

Wawrzyniak J., Władza a własność, czyli o wybranych problemach ewolucji stosunków między władzą polityczną a władzą ekonomiczną, (w:) J. Jabłońska-Bonca (red.), Krytyka prawa. Niezależne studium nad prawem. Tom I. Własność, Warszawa 2009.

Wilkin J., Rolnictwo a społeczeństwo - ewolucja funkcji i relacji, (w:) A. Rosner (red.), Uwarunkowania i kierunki przemian społeczno-gospodarczych na obszarach wiejskich, Warszawa 2005. 
Wilkin J., Uwarunkowania rozwoju polskiego rolnictwa w kontekście europejskim i globalnym. Referat przygotowany na VIII Kongres Ekonomistów Polskich „Polska w gospodarce światowej szanse i zagrożenia rozwoju" Warszawa, 29 listopada 2007 r., s. 17-18 - opracowanie dostępne na stronie internetowej: www.pte.pl/pliki/0/247/pte-kongreswilkin.doc (dostęp: 7.10.2016).

Woś A., Interwencjonizm państwowy i globalizacja w polityce rolnej, ,Zagadnienia Ekonomiki Rolnej” $2005, \mathrm{nr} 4$. 